1

\title{
Effects of different lipid sources on growth performance, body composition and lipid metabolism of bullfrog Lithobates \\ catesbeiana
}

Chun-xiao Zhang ${ }^{1, *}$, Kang-kang Huang ${ }^{1,2}$, Kang le Lu ${ }^{1}$, Ling Wang ${ }^{1}$, Kai Song ${ }^{1}$, Lu Zhang ${ }^{2}$, Peng $\mathrm{Li}^{3}$

${ }^{1 .}$ Xiamen Key Laboratory for Feed Quality Testing and Safety Evaluation, Fisheries College, Jimei University, Xiamen 361021, PR China

2. Tongwei Co., Ltd., Chengdu 610041, PR China

${ }^{3 .}$ National Renderers Association, Alexandra, VA, USA

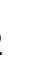
13 (4)

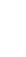
6

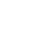

* Corresponding author: Tel.: +86 592 6181054; Fax: +86 592 6181054; E-mail: cxzhang@jmu.edu.cn (C.X. Zhang). 


\section{Abstract}

Fish oil is the most important lipid source, but its limited supply and high cost has forced the feed industry to investigate alternative lipid sources. The goal of this study was therefore to investigate effects of different lipid sources on growth performance, feed digestibility, body composition and lipid metabolism of bullfrog Lithobates catesbeiana. Bullfrogs were fed five diets containing $5.2 \%$ of either fish oil (FO), poultry fat (PF), pork lard (PL), soybean oil (SO) or palm oil (PO) for 8 weeks. Growth and feed utilization were significantly $(P<0.05)$ affected by different lipid sources. Weight gain and feed intake of bullfrogs fed diets with FO, SO and PO showed no significant difference. Body composition, feed conversion ratio and protein efficiency ratio of bullfrog were not affected by lipid sources. Apparent digestibility coefficients (ADC) of diets and test lipid ingredients were significantly $(P<0.05)$ different among all treatments; the highest ADC for lipid was observed in FO and SO, and the lowest value was found in PF. Fatty acid profiles of muscle reflected the fatty acid composition of dietary lipid source. The activities of hepatic enzymes related to lipid metabolism were significantly affected $(P<0.05)$ by lipid sources; the PF and PL groups had lower activities, compared to other groups. In conclusion, this study shows that fish oil can be totally replaced by SO or PO in bullfrog diets for a period of 8 weeks without negatively affecting growth performance. These alternative lipid sources have no effect on the body composition of bullfrog, while the fatty acid composition of muscle could be modified by lipid sources. Moreover, lipid sources could affect hepatic lipid metabolism of bullfrog.

Keywords: Bullfrog Lithobates catesbeiana, lipids sources, Fatty acid, Feeding and nutrition, Hepatic enzymes

\section{Introduction}


Dietary lipids are an important source of energy that play a prominent role in fish nutrition to provide energy, essential fatty acids (EFA) and phospholipids (Watanabe, 1982; Sargent et al., 2002).

Fish oil is the most important lipid source used in aquafeeds, as being rich in n-3 highly unsaturated fatty acid (HUFA) and typically a feed attractant. However, the annual global supply of fish oil is relatively constant and even decreased in recent years; whereas, the demand for fish oil in aquafeeds is continually increasing (Tacon and Metian, 2008). The limiting supply and high cost of fish oil have forced the industry to investigate alternative lipid sources for use in feeds, such as vegetable oils and rendered animal fat from beef, pork and poultry (Bell et al., 2001; Caballero et al., 2002; Ng et al., 2007; Stubhaug et al., 2007). Most lipids are well-utilized by animals (Trushenski and Lochmann, 2009; Trushenski and Ms, 2013), and fish oil sparing or replacement can be successful if essential fatty acid requirements are met.

Lithobates catesbeiana, known as the bullfrog, is native to North America and was introduced to China in the 1950s (Zhang et al., 2015). Bullfrog meat is a delicacy in many countries that has increased worldwide consumption (Pasteris et al., 2006). Moreover, other products such as the liver, gut and skin are required for other industries. Now, bullfrogs are commercially reared in frog farms in southeastern China due to its tender flesh, rapid growth, strong adaptability, efficient feed conversion and market value (Huang et al., 2014). In 2013, the production of bullfrog in China was estimated to be 150, 000 tons (Zhang et al., 2015). Therefore, it is important to study the nutritional requirements and feed formulations for bullfrog. In the past decade, the optimal dietary protein (Carmona-Osalde et al., 1996; Olvera-Novoa et al., 2007) and protein/lipid ratio (Huang et al., 2014)for bullfrog have been determined by various researchers. In recent years, replacement of fish oil in aquafeeds by other lipid sources has received heightened attention. However, effects of different dietary lipid sources for 
bullfrog culture have not been well studied. Therefore, this experiment was designed to evaluate effects of different lipid sources (fish oil, poultry fat, pork lard, soybean oil, and palm oil) on growth performance, body composition and lipid metabolism of bullfrog. The results may be helpful for the development of economical and quality artificial feeds for bullfrog.

\section{Materials and methods}

\subsection{Experimental diets}

Five iso-nitrogenous (40\%) and iso-energetic $\left(19.8 \mathrm{~kJ} \mathrm{~g}^{-1}\right)$ diets were formulated with fishmeal, casein and soybean meal as protein sources, fish oil, poultry fat, pork lard, soybean oil or palm oil as lipid sources and starch as the carbohydrate source. Each lipid source was supplemented at $5.2 \%$ in the experimental diets containing $1.4 \%$ crude lipid from fishmeal and $0.2 \%$ crude lipid from soybean meal.

The diets differed only in their lipid sources. Formulation, proximate composition and fatty acid composition of the experimental diets are presented in Table 1 and Table 2. Apparent digestibility coefficients were determined by using $0.5 \%$ chromic oxide as an inert indicator.

Prior to preparing the diets, the feed ingredients were ground and sieved, so the particles could pass through a $250-\mu \mathrm{m}$ sieve. The dry ingredients of each diet were mixed thoroughly in a mixer before lipid sources were added. Fish oil, poultry fat, pork lard, soybean oil and palm oil were poured into five conical flashes, respectively, and heated in the $60{ }^{\circ} \mathrm{C}$ hot bath until all lipid sources melted. After the melted oils were dispersed into mixture of each diet, water was added and mixed, respectively. Then the mixture was conveyed into a MY45 single screw extrusion machine (Xiamen fishing machinery feed machinery Co., Ltd.) with a 2.5 -mm die to produce neutrally buoyant $4.5 \times 6.5$-mm pellets. The pellets were dried to a moisture content of about $10 \%$ in a forced-air environment at $20^{\circ} \mathrm{C}$ for about 20 $\mathrm{h}$, and then stored at $-20{ }^{\circ} \mathrm{C}$ until used. 
2.2 Experimental bullfrogs and feeding trial

Bullfrogs were obtained from a commercial farm (Xiamen, China). Prior to the start of the experiment, bullfrogs were reared in indoor aquaria $(150 \times 70 \times 60 \mathrm{~cm})$ and fed a diet similar to the experimental diets without lipid for 15 days to acclimate to the experimental conditions. After the acclimation period, bullfrogs (initial body weight: $83.50 \pm 1.10 \mathrm{~g}$ ) were randomly sorted into 15 aquaria $(70 \times 40 \times 40 \mathrm{~cm})$ with an average water depth of $4 \mathrm{~cm}$. Each aquarium was stocked with 12 bullfrogs. Meanwhile, nine bullfrogs were randomly collected for analysis of initial whole-body composition. During the experimental period, bullfrogs were hand-fed to apparent satiation two times daily (8:00 and 17:00 h). Feed was consumed within $30 \mathrm{~min}$, and then the uneaten diet was collected, dried and weighted, after that, hundred-percent water was changed. Each diet was fed to bullfrogs in three replicates, and the trial lasted 8 weeks. Bullfrogs were held under indoor natural photoperiod (12D/12L) condition and temperature was $24-30{ }^{\circ} \mathrm{C}$ throughout the feeding trail.

2.3. Sample collection and analysis methods

\subsubsection{Sample collection}

At the end of the feeding trial, bullfrogs were starved for $24 \mathrm{~h}$ prior to sampling. Total number and weight of bullfrog in each cage were later determined. Samples of six bullfrogs per aquarium at the end of the feeding trial were randomly collected. Among them, two bullfrogs were sampled for analysis of whole-body composition, and four bullfrogs were used for determination for enzyme activities and muscle composition.

After the sampling, five bullfrogs per aquarium continued to feed with the same experimental diets with $0.5 \%$ chromic oxide for feces collection. The fecal samples for apparent digestibility coefficient were collected according to Zhang et al. (2015). Fecal samples from each aquarium were collected for a total of two weeks. 


\subsubsection{Experimental diet proximate analysis}

Feeds, whole body, muscle and feces were analyzed for proximate composition. Moisture was determined by oven drying at $105{ }^{\circ} \mathrm{C}$ until constant weight. Crude protein (nitrogen $\left.\times 6.25\right)$ was measured using an Auto Kjeldahl System (FOSS Kjeltec 8400, Switzerland); crude lipid by ether extraction; ash by incineration at $550{ }^{\circ} \mathrm{C}$ for $4 \mathrm{~h}$; and gross energy by an adiabatic bomb calorimeter (Parr 6300, USA). Chromic oxide in diets and feces were analyzed according to the method described by Furukawa and Tsukahara (1966).

\subsubsection{Fatty acid (FA) composition of feeds and bullfrog muscle}

The diet and muscle lipids were extracted with a chloroform: methanol $(2: 1 \mathrm{~V}: \mathrm{V})$ mixture according to Folch et al. (Folch et al., 1957). Fatty acids from lipid samples were methylated using 0.5 $\mathrm{mol} / \mathrm{l} \mathrm{NaOH}$ in methanol for $30 \mathrm{~min}$ at $60{ }^{\circ} \mathrm{C}$ and then esterified in $25 \%$ boron trifluoride in methanol. Methyl esters of fatty acids were then analyzed and quantified using a Shimadzu GC-201 gas chromatograph in a cross-linked 5\% phenylmethyl silicone gum phase column (length $30 \mathrm{~m}$; internal diameter $0.32 \mathrm{~mm}$; film thickness $0.25 \mathrm{~mm} ; \mathrm{N}_{2}$ as the carrier gas), equipped with flame ionization detection. The injector and detector temperatures were $250{ }^{\circ} \mathrm{C}$. The oven temperature was kept at $100{ }^{\circ} \mathrm{C}$ for $3 \mathrm{~min}$, raised to $180{ }^{\circ} \mathrm{C}$ at the rate of $10{ }^{\circ} \mathrm{C} / \mathrm{min}$ and then raised to $240{ }^{\circ} \mathrm{C}$ at $3{ }^{\circ} \mathrm{C} / \mathrm{min}$. The relative quantity of each FA present was determined by measuring the area under the chromatograph peak corresponding to that FA.

\subsubsection{Determination for activities of lipid-metabolizing enzymes}

Lipoprotein lipase (LPL), acetyl-coa carboxylase (ACC) and carnitine palmitoyltransferase (CPT I and II) are enzymes in lipid metabolism of animal. Liver were thawed and homogenized in nine volume of ice-cold buffer (10 mM HEPES, $1 \mathrm{mM}$ EDTA, $1 \mathrm{mM}$ dithiothreitol, pH 7.4). The extract 
134

was later centrifuged at $850 \times \mathrm{g}$ at $4{ }^{\circ} \mathrm{C}$ for $10 \mathrm{~min}$. The supernatant was used to determine activities using commercial kits, according to Zhang et al. (2012).

\subsection{Statistical analysis}

All data were presented as means of three replications and analyzed using one-way analysis of variance (ANOVA) and Turkey's multiple range tests. The level of significance was set at $P<0.05$. Analyses were performed using SPSS 17.0 (SPSS Inc., Michigan Avenue, Chicago, IL, USA).

\section{Results}

\subsection{Growth performance}

Survival was above $90 \%$ for all treatments, and was not significantly affected by diets. Weight gain of frogs fed diets with FO, SO and PO were significantly $(P<0.05)$ higher than those fed PF and PL. Moreover, feed intake of PF and PL groups were significantly $(P<0.05)$ lower than that of frogs fed the diet containing FO. The lowest feed intake was observed in bullfrog offered the PL diet. FCR, PER, nitrogen and energy retention did not showed difference $(P>0.05)$ among all dietary treatments (Table 3).

\subsection{Apparent digestibility coefficients of diets}

The ADCs of dry matter in diets containing FO and PO were significantly $(P<0.05)$ higher than that of the other treatments. Meanwhile, ADC of lipid for the FO and SO diets were highest, followed by the PL and PO diets, and the PF diet has the lowest lipid ADC. The ADCs of gross energy in FO and PO diets were significantly higher than that of the other groups. The variation for ADC of lipid and energy in lipid ingredients was the same as that in diets (Table 4).

\subsection{Whole-body and muscle composition}

Moisture, crude protein, crude lipid, crude ash and gross energy of whole body showed no 
156

157

158

significant differences among all groups. Moreover, only muscle lipid of bullfrog fed the PL and PO diets were significantly $(P<0.05)$ higher than that of bullfrogs fed the FO diet. Moisture, crude protein, crude ash and gross energy of muscle tissues showed no significant differences among all dietary treatments (Table 5).

The level of saturated fatty acids in bullfrog fed the PO diet was highest among all groups while bullfrogs fed the FO diet had the highest unsaturated fatty acids. There was no significant difference in eicosapentaenoic acid (EPA) among all groups. Moreover, the level of EPA + docosahexenoic acid (DHA) of bullfrog fed the FO diet was significantly higher $(P<0.05)$ than that of other groups $($ Table $6)$.

3.3 Activities of lipid-metabolizing enzymes in liver

All the activities of hepatic enzymes were significantly affected $(P<0.05)$ by dietary lipid source.

The activity of ACC from bullfrogs fed the PO diet showed the highest activity, and was significantly $(P<0.05)$ higher than that of bullfrogs fed the PF, PL and SO diets. The activity of LPL in liver of bullfrogs fed the PO diet was significantly $(P<0.05)$ higher than that of bullfrogs fed the PF and PL diets. The highest level of CPT I appeared in bullfrogs fed the PO diet, while these fed the PF diet had the lowest level. The activity of CPT II from bullfrogs fed the PO diet was significantly $(P<0.05)$ higher than that of bullfrogs fed the PF and PL diets (Table 7).

\section{Discussion}

With the increase in vegetable oil production, prices for the various products have been more stable and even decreased in some markets (Bell et al., 2004). Moreover, some animal fats (such as poultry fat, pork lard, and beef fat) are also used in feeds because of the low price and easy availability (Trushenski and Lochmann, 2009). Therefore, we chose vegetable oils and animal fats as alternative 
178

179

lipids to evaluate relative to fish oil in this study. Our present results indicated that fish oil can be successfully replaced with soybean or palm oil in bullfrog diets for a period of 8 weeks without affecting growth or nutrient utilization. The results are consistent with some previous studies showing the viability of total replacing dietary fish oil with soybean oil in some animals ( Rosenlund et al., 2001; Piedecausa et al., 2007). In this study, the fish oil diet had the highest level of polyunsaturated fatty acids (PUFA, such as EPA, DHA), while the soybean oil diet was rich in linolenic acid (18:2n-6). Dietary essential fatty acid (EFA) requirements of different species vary greatly. Reported estimates for freshwater fish species indicate that EFA requirements can be satisfied by the $\mathrm{C}_{18}$ PUFA (18:3n-3, 18:2n-6) (Tocher, 2010). Meanwhile, $\mathrm{C}_{18}$ PUFA can not satisfy the EFA requirements of marine fish, and so the n-3 PUFA (EPA, DHA) are required (Tocher, 2010). To our knowledge, the EFA requirements of bullfrog are still unknown. It is possible that bullfrog may not require dietary n-3 PUFA (EPA, DHA) for optimal growth either. It is also possible that the SO and PO diets could supply enough EFA to maintain the physiological needs of the bullfrog during the feeding period. Weight gain of bullfrog fed the PF and PL diets was lower than that of other groups, which may be explained by reduced feed intake. It has been reported that lipid sources may regulate food intake through pre- or post-absorptive mechanisms, such as through effects on palatability (Morais et al., 2006). Therefore, in the present study, the low feed intake may be related to palatability characteristics of the diets as the palatability of poultry fat and pork lard may be poorer than fish oil and other vegetable oils (Trushenski and Lochmann, 2009).

Digestibility is one of the most important aspects in evaluating the suitability of feed ingredients for a given species (Luo et al., 2008). Some studies have shown that the growth of an animal may be closely associated with apparent digestibility coefficients (ADCs) of nutrients in the diets (Mozanzadeh 
et al., 2016). In the current study, ADCs also were affected by the different lipid sources. ADCs of nutrients in the FO and PO diets were higher than those of the other diets, which may account for the better growth of bullfrogs fed these two diets.

It has been reported that fatty acid composition of dietary lipids can alter body composition in many animal species (Greene and Selivonchick, 1990). In our present study, body composition of bullfrogs fed different diets did not show significant differences. However, dietary lipid sources did affect muscle lipid level of bullfrog with these fed the PL and PO diets having higher level than these fed FO diets. This may be explained by the high levels of saturated fatty acid (SFA) (40.67\% and $47.53 \%$ ) in the PL and PO diets. Some studies have reported that SFAs are more easy to deposit in tissues than monounsaturated fatty acid (MUFA) and PUFA (Clarke et al., 1990) .

Reports have shown that fatty acid composition of diets can alter body or muscle fatty acid composition in many animal species (Huang et al., 2001; Higgs et al., 2006; Du et al., 2008). This phenomenon was also observed in muscle lipids of the bullfrog in the present study. It was interesting that DHA level in muscle tissue was higher than that in diets, while it was opposite for the level of EPA. The fatty acid composition of tissue lipids is the momentary net result of complex dynamic interrelationships among a number of factors, including dietary fatty acid intake, and oxidative catabolism of fatty acid (Lie et al., 1993; Du et al., 2008). DHA is reported to be essentially oxidized within peroxisomes and is a poor substrate for fatty acid oxidation. Thus, high DHA level in the muscle of bullfrog may be associated with a weak peroxisomal fatty acid oxidation activity.

Many reports have shown that dietary fatty acid could influence lipid metabolism of animals (An et al., 1997; González-Durán et al., 2008). The liver fulfills numerous functions and is the major site of lipid metabolism (Lu et al., 2014). Therefore, we studied the effect of lipid sources on the main 
lipid-metabolizing enzymes in the liver of bullfrogs. Acetyl CoA carboxylase (ACC) is the rate-limiting enzymes during the process of fatty acid synthesis (Leaver et al., 2008). The present results showed that bullfrogs fed the PL and PO diets had the lowest and highest levels of ACC activity, respectively. However, the FA composition of these two diets was similar. This phenomenon may be related to intake lipid, and the intake of the PL diet was lowest among all groups. Lipoprotein lipase (LPL) plays a key role in lipid metabolism by hydrolyzing triglycerides transported in the bloodstream as very low-density lipoproteins and intestinally derived chylomicrons, providing free fatty acid for uptake by the tissues for storage or oxidation ( $\mathrm{Li}$ et al., 2013). Many studies have shown that dietary fatty acid composition and lipid level could affect LPL activity (Liang et al., 2002; Li et al., 2013). The present result showed that the lowest LPL activity appeared in bullfrogs fed the PF diet. The low LPL activity could lower liver tissue fatty acid uptake, which may imply inactive lipid metabolism. Carnitine palmitoyltransferase system (CPT I and II) is considered to be the key regulatory enzyme in mitochondrial $\beta$-oxidation because it catalyzes the conversion of fatty acyl-CoAs into fatty acyl-carnitine molecules for entry into the mitochondrial matrix (Kerner and Hoppel, 2000). The SFA in animal lipid was reported to be preferentially used as oxidation substrates through the mitochondrial pathway. Therefore, the high level of SFA in the PO diet may explain the higher activities of CPT I and II in liver of bullfrog fed these diets. Based the hepatic enzyme activities, we considered that the lipid metabolism of bullfrog fed diets with animal fat (poultry fat and pork lard) was not very active.

In conclusion, this study showed that fish oil can be total replaced by soybean oil or palm oil in bullfrog diets for a period of 8 weeks without negatively affecting the growth performance. These alternative lipid sources have no effect on the body composition of bullfrog, while the FA composition of muscle could be modified and had close correlation to fatty acid composition of the diets. Moreover, 
the present study shows that the lipid sources could affect hepatic lipid metabolism of bullfrog as PL and PF diets decreased the activities of enzymes related to lipid metabolism.

\section{Acknowledgments}

This work was funded by National Natural Science Foundation of China (Grant No. 31572625),

Special Fund for Agro-scientific Research in the Public Interest (201303053) and USDA Market

Access Program. We thank Xiamen Yinhao Feed Co., Ltd. and Fuxing (Xiamen) Organic Feed Co., Ltd.

for donating feed ingredients. We would like also to thank Xian Zhang for her contribution in analyses.

\section{References}

An, B.K., Banno, C., Zhong, S.X., Tanaka, K., Ohtani, S., 1997. Effects of dietary fat sources on lipid metabolism in growing chicks (Gallus domesticus). Comparative Biochemistry \& Physiology Part B Biochemistry \& Molecular Biology. 116, 119-125.

Bell, J., Mcevoy, J., Dr, Mcghee, F., Campbell, P., Sargent, J., 2001. Replacement of fish oil with rapeseed oil in diets of Atlantic salmon (Salmo salar) affects tissue lipid compositions and hepatocyte fatty acid metabolism. Journal of Nutrition. 131, 1535-1543.

Bell, J.G., Henderson, R.J., Tocher, D.R., Sargent, J.R., 2004. Replacement of dietary fish oil with increasing levels of linseed oil: Modification of flesh fatty acid compositions in Atlantic salmon (Salmo salar) using a fish oil finishing diet. Lipids. 39, 223-232.

Caballero, M.J., Obach, A., Rosenlund, G., Montero, D., Gisvold, M., Izquierdo, M.S., 2002. Impact of different dietary lipid sources on growth, lipid digestibility, tissue fatty acid composition and histology of rainbow trout, Oncorhynchus mykiss. Aquaculture. 214, 253-271.

Carmona-Osalde, C., Olvera-Novoa, M.A., Rodríguez-Serna, M., Flores-Nava, A., 1996. Estimation of the protein requirement for bullfrog (Rana catesbeiana) tadpoles, and its effect on metamorphosis ratio. Aquaculture. 141, 223-231.

Clarke, S.D., Armstrong, M.K., Jump, D.B., 1990. Dietary polyunsaturated fats uniquely suppress rat liver fatty acid synthase and S14 mRNA content. Journal of Nutrition. 120, 225-231.

Du, Z.Y., Clouet, P., Huang, L.M., Degrace, P., Zheng, W.H., He, J.G., Tian, L.X., Liu, Y.J., 2008. Utilization of different dietary lipid sources at high level in herbivorous grass carp (Ctenopharyngodon idella): mechanism related to hepatic fatty acid oxidation. Aquaculture Nutrition. 14, 77-92.

Folch, J., Lees, M., Stanley, G.H.S., 1957. A simple method for the isolation and purification of total lipids from animal tissues. Mccarthy. 226, 497-509.

Furukawa, Tsukahara, H., 1966. On the acid digestion method for the determination of chromic oxide as an index substance in the study of digestibility of fish feed. Nihon-suisan-gakkai-shi. 32, 502-508.

González-Durán, E., Castell, J.D., Robinson, S.M.C., Blair, T.J., 2008. Effects of dietary lipids on the fatty acid composition and lipid metabolism of the green sea urchin Strongylocentrotus droebachiensis. Aquaculture. 276, 120-129. 
Greene, D.H.S., Selivonchick, D.P., 1990. Effects of dietary vegetable, animal and marine lipids on muscle lipid and hematology of rainbow trout (Oncorhynchus mykiss). Aquaculture. 89, 165-182.

Higgs, D.A., Balfry, S.K., Oakes, J.D., et al., 2006. Efficacy of an equal blend of canola oil and poultry fat as an alternate dietary lipid source for Atlantic salmon (Salmo salar L.) in sea water. I: effects on growth performance, and whole body and fillet proximate and lipid composition. Aquaculture Research. 37, 180-191.

Huang, C.H., Shyong, W.J., Lin, W.Y., 2001. Dietary lipid supplementation affects the body fatty acid composition but not the growth of juvenile river chub, Zacco barbata (Regan). Aquaculture Research. 32, 1005-1010.

Huang. K.K., Zhang, C.X., Wang, L., Song, K., Huang, F., 2014. Effect of dietary protein and lipid levels on growth of bullforg (Rana catesbeiana). Journal of Fisheries 38, 877-887. (Chinese with English abstract).

Kerner, J., Hoppel, C., 2000. Fatty acid import into mitochondria. Biochimica Et Biophysica Acta. $1486,1-17$.

Leaver, M.J., Bautista, J.M., Björnsson, B.T., Jönsson, E., Krey, G., Tocher, D.R., Torstensen, B.E., 2008. Towards Fish Lipid Nutrigenomics: Current State and Prospects for Fin-Fish Aquaculture. Reviews in Fisheries Science. 16, 73-94.

Li, X.F., Qian, Y., Jiang, G.Z., Xu, W.N., Liu, W.B., 2013. Molecular characterization of lipoprotein lipase from blunt snout bream Megalobrama amblycephala and the regulation of its activities and expression by dietary lipid levels. Aquaculture. 416-417.

Liang, X.F., Ogata, H.Y., Oku, H., 2002. Effect of dietary fatty acids on lipoprotein lipase gene expression in the liver and visceral adipose tissue of fed and starved red sea bream Pagrus major. Comparative Biochemistry \& Physiology Part A Molecular \& Integrative Physiology. 132, 913-919.

Lie, Ø., Sandvin, A., Waagbø, R., 1993. Influence of dietary fatty acids on the lipid composition of lipoproteins in farmed Atlantic salmon (Salmo salar). Fish Physiology \& Biochemistry. 12, 249-260.

Lu, K.L., Xu, W.N., Wang, L.N., Zhang, D.D., Zhang, C.N., Liu, W.B., 2014. Hepatic $\beta$-oxidation and regulation of carnitine palmitoyltransferase (CPT) I in blunt snout bream Megalobrama amblycephala fed a high fat diet. Plos One. 9, e93135.

Luo, Z., Tan, X.Y., Chen, Y.D., Wang, W.M., Zhou, G., 2008. Apparent digestibility coefficients of selected feed ingredients for Chinese mitten crab Eriocheir sinensis. Aquaculture. 285, $141-145$.

Morais, S., Torten, M., Nixon, O., Lutzky, S., Conceição, L.E.C., Dinis, M.T., Tandler, A., Koven, W., 2006. Food intake and absorption are affected by dietary lipid level and lipid source in seabream (Sparus aurata L.) larvae. Journal of Experimental Marine Biology \& Ecology. 331, 51-63.

Mozanzadeh, M.T., Agh, N., Yavari, V., Marammazi, J.G., Mohammadian, T., Gisbert, E., 2016. Partial or total replacement of dietary fish oil with alternative lipid sources in silvery-black porgy (Sparidentex hasta). Aquaculture. 451, 232-240.

Ng, W.K., Tocher, D.R., Bell, J.G., 2007. The use of palm oil in aquaculture feeds for salmonid species. European Journal of Lipid Science \& Technology. 109, 394-399.

Olvera-Novoa, M.A., Ontiveros-Escutia, V.M., Flores-Nava, A., 2007. Optimum protein level for 
growth in juvenile bullfrog (Rana catesbeiana Shaw, 1802). Aquaculture. 266, 191-199.

Pasteris, S.E., Bühler, M.I., Nader-Macías, M.E., 2006. Microbiological and histological studies of farmed-bullfrog (Rana catesbeiana) tissues displaying red-leg syndrome. Aquaculture. 251, 11-18.

Piedecausa, M.A., Mazón, M.J., García, B.G., Hernández, M.D., 2007. Effects of total replacement of fish oil by vegetable oils in the diets of sharpsnout seabream (Diplodus puntazzo). Aquaculture. 263, 211-219.

Rosenlund, G., Obach, A., Sandberg, M.G., Standal, H., Tveit, K., 2001. Effect of alternative lipid sources on long-term growth performance and quality of Atlantic salmon (Salmo salar L.). Aquaculture Research. 32, 323-328(326).

Sargent, J.R., Tocher, D.R., Bell, J.G., 2002. The lipids. Fish nutrition. 3, 181-257.

Stubhaug, I., Lie, Ø., Torstensen, B.E., 2007. Fatty acid productive value and $\beta$ - oxidation capacity in Atlantic salmon (Salmo salar L.) fed on different lipid sources along the whole growth period. Aquaculture Nutrition. 13, 145-155.

Tacon, A.G.J., Metian, M., 2008. Global overview on the use of fish meal and fish oil in industrially compounded aquafeeds: Trends and future prospects. Aquaculture. 285, 146-158.

Trushenski, J.T., Lochmann, R.T., 2009. Potential, Implications and Solutions Regarding the Use of Rendered Animal Fats in Aquafeeds. American Journal of Animal \& Veterinary Sciences. 4, 108-128.

Trushenski, J.T., Ms, J.C.B., 2013. Having Your Omega 3 Fatty Acids and Eating Them Too: Strategies to Ensure and Improve the Long-Chain Polyunsaturated Fatty Acid Content of Farm-Raised Fish. Nutrition \& Health.

Tocher, D.R., 2010. Fatty acid requirements in ontogeny of marine and freshwater fish. Aquaculture Research. 41, 717-732.

Watanabe, T., 1982. Lipid nutrition in fish. Comparative Biochemistry \& Physiology B Comparative Biochemistry. 73, 3-15.

Zhang, C.X., Huang, K.K., Wang, L., Song, K., Zhang, L., Li, P., 2015. Apparent digestibility coefficients and amino acid availability of common protein ingredients in the diets of bullfrog, Rana (Lithobates) catesbeiana. Aquaculture, 38-45.

Zhang, Y.Y., Liu, B., Ge, X.P., Liu, W.B., Xie, J., Gao,.Q.P., Gu, X.Z., 2012. Effect of dietary oil sources on growth performance, body composition, the serum biochemical indices, fatty acids composition and lipid metabolism of Carassius auratus gibelio. Journal of Fisheries 36, 1111-1119. (Chinese with English abstract). 
Table 1. Formulation and proximate composition of the experimental diets fed to bullfrogs (\% dry-matter basis).

\begin{tabular}{|c|c|c|c|c|c|}
\hline Ingredients (\%) & $\mathrm{FO}^{7}$ & $\mathrm{PF}^{7}$ & $\mathrm{PL}^{7}$ & $\mathrm{SO}^{7}$ & $\mathrm{PO}^{7}$ \\
\hline Menhaden fish meal ${ }^{1}$ & 20.00 & 20.00 & 20.00 & 20.00 & 20.00 \\
\hline Casein $^{2}$ & 10.00 & 10.00 & 10.00 & 10.00 & 10.00 \\
\hline Soybean meal ${ }^{3}$ & 36.00 & 36.00 & 36.00 & 36.00 & 36.00 \\
\hline$\alpha$-Starch & 26.07 & 26.07 & 26.07 & 26.07 & 26.07 \\
\hline Fish oil & 5.20 & - & - & - & - \\
\hline Poultry fat & - & 5.20 & - & - & - \\
\hline Pork lard & - & - & 5.20 & - & - \\
\hline Soybean oil & - & - & - & 5.20 & - \\
\hline Palm oil & - & - & - & - & 5.20 \\
\hline Choline chloride & 0.50 & 0.50 & 0.50 & 0.50 & 0.50 \\
\hline Mineral premix ${ }^{4}$ & 0.50 & 0.50 & 0.50 & 0.50 & 0.50 \\
\hline Vitamin premix ${ }^{5}$ & 0.10 & 0.10 & 0.10 & 0.10 & 0.10 \\
\hline Mold inhibitor ${ }^{6}$ & 0.05 & 0.05 & 0.05 & 0.05 & 0.05 \\
\hline Ethoxyquin & 0.03 & 0.03 & 0.03 & 0.03 & 0.03 \\
\hline L-Ascorbic acid polyphosphate & 0.05 & 0.05 & 0.05 & 0.05 & 0.05 \\
\hline Monocalcium phosphate & 1.50 & 1.50 & 1.50 & 1.50 & 1.50 \\
\hline \multicolumn{6}{|l|}{ Proximate composition (\%) } \\
\hline Moisture & 9.60 & 10.90 & 12.00 & 9.50 & 10.70 \\
\hline Crude protein & 40.10 & 40.60 & 39.90 & 39.70 & 39.90 \\
\hline Crude lipid & 7.03 & 6.81 & 6.96 & 7.06 & 6.99 \\
\hline Crude ash & 8.10 & 8.30 & 8.20 & 8.00 & 8.20 \\
\hline Gross energy (kJ/g) & 19.80 & 19.80 & 19.80 & 19.90 & 19.80 \\
\hline
\end{tabular}

$361{ }^{1}$ Menhaden fish meal, obtained from Tecnológica de Alimentos S.A, Peru;

$362 \quad{ }^{2}$ Casein, obtained from Gansu Hualing Casein Co., Ltd.

$363{ }^{3}$ Soybean meal, obtained from Quanzhou Fuhai cereals and oils industry Co., Ltd;

$364{ }^{4}$ Mineral premix (mg or g/kg diet): $\mathrm{NaF}, 2 \mathrm{mg} ; \mathrm{KI}, 0.8 \mathrm{mg} ; \mathrm{CoCl}_{2} \cdot 6 \mathrm{H}_{2} \mathrm{O}(1 \%), 50 \mathrm{mg} ; \mathrm{CuSO}_{4} \cdot 5 \mathrm{H}_{2} \mathrm{O}, 10 \mathrm{mg} ; \mathrm{FeSO}_{4} \cdot \mathrm{H}_{2} \mathrm{O}, 80 \mathrm{mg} ; \mathrm{ZnSO}_{4} \cdot \mathrm{H}_{2} \mathrm{O}, 50 \mathrm{mg}$;

$365 \mathrm{MnSO}_{4} \cdot \mathrm{H}_{2} \mathrm{O}, 25 \mathrm{mg} ; \mathrm{MgSO}_{4} \cdot 7 \mathrm{H}_{2} \mathrm{O}, 200 \mathrm{mg}$; Zoelite, $4.55 \mathrm{~g}$.

$366{ }^{5}$ Vitamin premix ( $\mathrm{mg}$ or g/ $\mathrm{kg}$ diet): thiamin, 10mg; riboflavin, 8mg; pyridoxine $\mathrm{HCl}, 10 \mathrm{mg}$; vitamin B12, $0.03 \mathrm{mg}$, vitamin $\mathrm{K} 3,10 \mathrm{mg}$;

367 inositol, 100mg; pantothenic acid, 20mg; niacin acid, 50mg; folic acid, 2mg; biotin, 0.2mg; retinol acetate, 400mg; cholecalciferol, 5mg;

368 alpha-tocopherol, 100mg; ethoxyquin, 150mg; wheat middling, 1.135g.

$369{ }^{6} 50 \%$ calcium propionic acid and $50 \%$ fumaric acid.

$370 \quad{ }^{7}$ FO, Fish oil; PF, PF, Poultry fat; PL, Pork lard; SO, Soybean oil; PO, Palm oil. 
Table 2. Fatty acid composition of the experimental diets fed to bullfrogs (\% of total fatty acid).

\begin{tabular}{|c|c|c|c|c|c|}
\hline Fatty acid & $\mathrm{FO}^{5}$ & $\mathrm{PF}^{5}$ & $\mathrm{PL}^{5}$ & $\mathrm{SO}^{5}$ & $\mathrm{PO}^{5}$ \\
\hline C14:0 & 4.08 & 1.46 & 1.89 & 1.14 & 1.69 \\
\hline C16:0 & 21.35 & 25.92 & 27.13 & 14.05 & 39.96 \\
\hline C18:0 & 4.77 & 6.33 & 11.65 & 4.66 & 5.88 \\
\hline C16:1n-9 & 8.36 & 6.78 & 5.67 & 3.65 & 3.68 \\
\hline C18:1n-9 & 12.60 & 12.41 & 15.36 & 12.64 & 9.51 \\
\hline$C 18: 2 n-6$ & 2.59 & 21.99 & 21.30 & 46.61 & 15.04 \\
\hline C18:3n-3 & 3.85 & 1.98 & 2.48 & 1.95 & 1.82 \\
\hline$C 20: 3 n-6$ & 2.84 & 1.98 & 0.00 & 1.55 & 1.50 \\
\hline$C 20: 4 n-6$ & 7.95 & 2.55 & 2.53 & 2.17 & 3.14 \\
\hline$C 20: 5 n-3$ & 9.80 & 3.99 & 4.38 & 3.56 & 4.34 \\
\hline$C 22: 6 n-3$ & 8.48 & 2.85 & 3.04 & 3.13 & 2.46 \\
\hline $\mathrm{SFA}^{1}$ & 30.20 & 33.72 & 40.67 & 19.85 & 47.53 \\
\hline MUFA $^{2}$ & 20.96 & 19.19 & 21.02 & 16.29 & 13.19 \\
\hline PUFA $^{3}$ & 35.51 & 35.35 & 33.72 & 58.96 & 28.29 \\
\hline$E P A+D H A^{4}$ & 18.28 & 6.84 & 7.42 & 6.69 & 6.80 \\
\hline
\end{tabular}

$372{ }^{1}$ SFA: Saturated fatty acid.

$373 \quad{ }^{2}$ MUFA: Monounsaturated fatty acid.

$374{ }^{3}$ PUFA: Polyunsaturated fatty acid.

$375{ }^{4}$ EPA: Eicosapentaenoic acid. DHA: Docosahexenoic acid.

$376{ }^{5}$ FO, Fish oil; PF, PF, Poultry fat; PL, Pork lard; SO, Soybean oil; PO, Palm oil.

377 
Table 3. Effect of different lipid sources on growth performance of bullfrogs ${ }^{1}$

\begin{tabular}{|c|c|c|c|c|c|c|c|}
\hline Diets & $\begin{array}{c}\text { Weight } \\
\text { gain ratio }(\%)^{2}\end{array}$ & $\begin{array}{c}\text { Feed } \\
\text { intake }(\% / d)^{3}\end{array}$ & $\mathrm{FCR}^{4}$ & PER $^{5}$ & Nitrogen retention ${ }^{6}$ & Energy retention $^{7}$ & $\begin{array}{c}\text { Survival } \\
\text { (\%) }\end{array}$ \\
\hline $\mathrm{FO}^{8}$ & $180.9^{\mathrm{a}}$ & $1.40^{\mathrm{a}}$ & 0.82 & 3.06 & 49.70 & 41.00 & 97.20 \\
\hline $\mathrm{PF}^{8}$ & $170.3^{b}$ & $1.33^{b c}$ & 0.81 & 3.07 & 49.90 & 43.50 & 100.0 \\
\hline $\mathrm{PL}^{8}$ & $171.2^{b}$ & $1.28^{\mathrm{C}}$ & 0.78 & 3.22 & 53.80 & 43.60 & 97.20 \\
\hline $\mathrm{SO}^{8}$ & $185.2^{\mathrm{a}}$ & $1.34^{\mathrm{abc}}$ & 0.80 & 3.14 & 48.30 & 41.80 & 97.20 \\
\hline $\mathrm{PO}^{8}$ & $179.8^{\mathrm{a}}$ & $1.37^{\mathrm{ab}}$ & 0.81 & 3.08 & 50.90 & 41.40 & 94.40 \\
\hline Pooled SE & 1.70 & 0.01 & 0.01 & 0.02 & 1.01 & 0.54 & 1.33 \\
\hline$P$ value & 0.001 & 0.002 & 0.07 & 0.05 & 0.56 & 0.43 & 0.83 \\
\hline
\end{tabular}
$(P<0.05)$.

${ }^{2}$ Weight gain ratio $=($ Final body weight-initial body weight $) \times 100 /$ initial body weight.

${ }^{3}$ Feed intake $(\mathrm{Fl} ; \%$ body weight $/ \mathrm{d})=[$ feed intake $(\mathrm{g}) \times 100] /[(\mathrm{WO}+\mathrm{Wt}) \times \mathrm{T} / 2]$, where $\mathrm{W} 0$ and $\mathrm{Wt}$ are the initial and final body weights, and $\mathrm{T}$ is feeding days.

${ }^{4}$ Feed conversion ratio $(F C R)=$ total diet fed $(\mathrm{kg}) /$ total wet weight gain $(\mathrm{kg})$.

${ }^{5}$ Protein efficiency ratio $(P E R)=$ bullfrog wet weight gain /protein intake.

${ }^{6,7}$ Retention of nitrogen and energy $(\%)=[(\mathrm{Wt} \times \mathrm{Ct})-(\mathrm{W} 0 \times \mathrm{C} 0)] \times 100 /\left(\mathrm{C}_{\text {diet }} \times \mathrm{feed}\right.$ intake), where W0 and Wt are the initial and final body weights, $\mathrm{CO}$ and $\mathrm{Ct}$ are the initial and final contents in whole body respectively, and $\mathrm{C}_{\text {diet }}$ is the content in the diets.

Table 4. Effect of different lipid sources on the dietary apparent digestibility coefficients of bullfrogs

\begin{tabular}{|c|c|c|c|c|c|}
\hline & \multicolumn{3}{|c|}{ Diets } & \multicolumn{2}{|c|}{ Lipid ingredients } \\
\hline & Dry matter & Lipid & Gross energy & Lipid & Gross energy \\
\hline $\mathrm{FO}^{2}$ & $83.20^{\mathrm{a}}$ & $94.10^{\mathrm{a}}$ & $86.50^{\mathrm{a}}$ & $97.00^{\mathrm{a}}$ & $115.6^{a}$ \\
\hline $\mathrm{PF}^{2}$ & $80.90^{b}$ & $84.30^{c}$ & $83.70^{b}$ & $83.30^{c}$ & $88.70^{b}$ \\
\hline $\mathrm{PL}^{2}$ & $81.10^{b}$ & $91.20^{b}$ & $84.50^{b}$ & $92.80^{b}$ & $95.80^{b}$ \\
\hline $\mathrm{SO}^{2}$ & $80.20^{b}$ & $93.30^{\mathrm{a}}$ & $83.70^{b}$ & $95.80^{\mathrm{a}}$ & $87.80^{b}$ \\
\hline $\mathrm{PO}^{2}$ & $83.80^{a}$ & $92.70^{\mathrm{ab}}$ & $86.50^{\mathrm{a}}$ & $94.90^{\mathrm{ab}}$ & $115.6^{\mathrm{a}}$ \\
\hline Pooled SE & 0.40 & 1.00 & 0.40 & 1.30 & 3.50 \\
\hline$P$ value & $<0.001$ & $<0.001$ & $<0.001$ & $<0.001$ & $<0.001$ \\
\hline
\end{tabular}

$391{ }^{1}$ Values are presented as means of three replications. Means in the same column with different superscripts are significantly different $392 \quad(P<0.05)$.

$393 \quad{ }^{2}$ FO, Fish oil; PF, PF, Poultry fat; PL, Pork lard; SO, Soybean oil; PO, Palm oil. 
Table 5. Effect of different lipid sources on the whole-body and muscle composition of bullfrogs

\begin{tabular}{|c|c|c|c|c|c|c|c|}
\hline & $\mathrm{FO}^{2}$ & $\mathrm{PF}^{2}$ & $\mathrm{PL}^{2}$ & $\mathrm{SO}^{2}$ & $\mathrm{PO}^{2}$ & Pooled SE & $P$ value \\
\hline \multicolumn{8}{|l|}{ Whole body } \\
\hline Moisture (\%) & 75.80 & 75.60 & 75.80 & 76.00 & 75.60 & 0.15 & 0.92 \\
\hline Crude protein (\%) & 15.15 & 15.07 & 15.40 & 14.57 & 15.29 & 0.20 & 0.80 \\
\hline Crude lipid (\%) & 5.48 & 6.20 & 5.41 & 5.74 & 5.50 & 0.13 & 0.30 \\
\hline Crude ash (\%) & 2.60 & 2.53 & 2.61 & 2.55 & 2.52 & 0.04 & 0.93 \\
\hline Gross energy (kJ/g) & 5.87 & 6.07 & 5.88 & 5.84 & 5.87 & 0.05 & 0.65 \\
\hline \multicolumn{8}{|l|}{ Muscle } \\
\hline Moisture (\%) & 80.44 & 80.25 & 80.28 & 80.13 & 80.17 & 0.10 & 0.92 \\
\hline Crude protein (\%) & 18.27 & 18.47 & 18.36 & 18.64 & 18.61 & 0.10 & 0.77 \\
\hline Crude lipid (\%) & $0.27^{\mathrm{a}}$ & $0.32^{\mathrm{ab}}$ & $0.38^{\mathrm{b}}$ & $0.34^{\mathrm{ab}}$ & $0.39^{\mathrm{b}}$ & 0.02 & 0.01 \\
\hline Crude ash (\%) & 0.97 & 0.92 & 0.94 & 0.95 & 0.94 & 0.01 & 0.69 \\
\hline Gross energy (kJ/g) & 4.34 & 4.39 & 4.38 & 4.44 & 4.43 & 0.03 & 0.84 \\
\hline
\end{tabular}

${ }^{1}$ Values are presented as means of three replications. Means in the same row with different superscripts are significantly different $(P<0.05)$.

$398 \quad{ }^{2}$ FO, Fish oil; PF, PF, Poultry fat; PL, Pork lard; SO, Soybean oil; PO, Palm oil. 
Table 6. Effect of different lipid sources on fatty acid composition of muscle from bullfrogs (\% of total fatty acid) ${ }^{1}$

\begin{tabular}{|c|c|c|c|c|c|c|c|}
\hline Fatty acid (\%) & $\mathrm{FO}^{6}$ & $\mathrm{PF}^{6}$ & $\mathrm{PL}^{6}$ & $\mathrm{SO}^{6}$ & $\mathrm{PO}^{6}$ & Pooled SE & $P$ value \\
\hline C14:0 & $1.33^{\mathrm{a}}$ & $0.93^{b}$ & $1.06^{b}$ & $0.91^{b}$ & $0.95^{b}$ & 0.04 & 0.00 \\
\hline C15:0 & 2.31 & 1.83 & 2.26 & 1.93 & 1.95 & 0.08 & 0.28 \\
\hline C16:0 & $30.24^{b}$ & $28.82^{b}$ & $29.77^{b}$ & $27.20^{\mathrm{b}}$ & $34.30^{\mathrm{a}}$ & 0.70 & 0.001 \\
\hline C18:0 & $6.97^{\mathrm{ab}}$ & $6.60^{b}$ & $7.88^{\mathrm{a}}$ & $6.98^{\mathrm{ab}}$ & $7.53^{\mathrm{ab}}$ & 0.15 & 0.02 \\
\hline C16:1n-9 & $8.04^{a}$ & $6.61^{\mathrm{ab}}$ & $7.32^{\mathrm{ab}}$ & $5.77^{\mathrm{b}}$ & $6.87^{\mathrm{ab}}$ & 0.25 & 0.02 \\
\hline C18:1n-9 & 14.51 & 12.03 & 14.62 & 12.26 & 12.80 & 0.44 & 0.15 \\
\hline$C 18: 2 n-6$ & $4.13^{c}$ & $17.10^{\mathrm{ab}}$ & $9.27^{b c}$ & $23.02^{\mathrm{a}}$ & $11.43^{b c}$ & 1.88 & 0.00 \\
\hline C18:3n-3 & 1.75 & 1.63 & 1.69 & 1.73 & 1.63 & 0.03 & 0.63 \\
\hline$C 20: 3 n-6$ & 2.43 & 1.82 & 2.20 & 1.84 & 1.99 & 0.87 & 0.11 \\
\hline$C 20: 4 n-6$ & $7.28^{c}$ & $5.30^{\mathrm{ab}}$ & $5.21^{\mathrm{ab}}$ & $4.45^{\mathrm{a}}$ & $6.04^{b}$ & 0.27 & 0.00 \\
\hline$C 20: 5 n-3$ & 2.47 & 2.28 & 2.68 & 2.37 & 2.39 & 0.07 & 0.47 \\
\hline$C 22: 6 n-3$ & $9.40^{\mathrm{a}}$ & $7.20^{\mathrm{b}}$ & $6.80^{\mathrm{b}}$ & $6.45^{\mathrm{b}}$ & $7.39^{b}$ & 0.29 & 0.00 \\
\hline SFA $^{2}$ & $40.85^{\mathrm{ab}}$ & $38.18^{\mathrm{a}}$ & $40.97^{\mathrm{ab}}$ & $37.02^{b}$ & $44.74^{\mathrm{a}}$ & 0.81 & 0.00 \\
\hline MUFA $^{3}$ & 22.55 & 18.64 & 21.95 & 18.03 & 19.68 & 0.64 & 0.07 \\
\hline PUFA $^{4}$ & $27.45^{c}$ & $35.33^{\mathrm{ab}}$ & $27.85^{b c}$ & $39.85^{a}$ & $30.86^{b c}$ & 1.40 & 0.001 \\
\hline$E P A+D H A^{5}$ & $11.87^{\mathrm{a}}$ & $9.47^{b}$ & $9.47^{b}$ & $8.81^{b}$ & $9.78^{b}$ & 0.34 & 0.00 \\
\hline
\end{tabular}

$401{ }^{1}$ Values are presented as means of three replications. Means in the same row with different superscripts are significantly different

$402 \quad(P<0.05)$.

$403{ }^{2}$ SFA: Saturated fatty acid.

$404 \quad{ }^{3}$ MUFA: Monounsaturated fatty acid.

$405 \quad{ }^{4}$ PUFA: Polyunsaturated fatty acid.

$406{ }^{5}$ EPA: Eicosapentaenoic acid. DHA: Docosahexenoic acid.

$407 \quad{ }^{6}$ FO, Fish oil; PF, PF, Poultry fat; PL, Pork lard; SO, Soybean oil; PO, Palm oil. 
Table 7. Effect of different lipid sources on activities of hepatic enzymes related to lipid metabolism for bullfrogs ${ }^{1}$

\begin{tabular}{lllll}
\hline Diets & $\mathrm{ACC}^{2}$ (ng/g prot $)$ & $\mathrm{LPL}^{3}$ (U/g prot) & $\mathrm{CPT} \mathrm{I}^{4}(\mathrm{U} / \mathrm{g}$ prot $)$ & $\mathrm{CPT} \mathrm{I}^{5}$ (U/g prot) \\
\hline $\mathrm{FO}^{6}$ & $159.7^{\mathrm{ab}}$ & $68.30^{\mathrm{ab}}$ & $20.90^{\mathrm{ab}}$ & $13.20^{\mathrm{ab}}$ \\
$\mathrm{PF}^{6}$ & $123.0^{\mathrm{cd}}$ & $52.80^{\mathrm{c}}$ & $15.80^{\mathrm{c}}$ & $11.50^{\mathrm{b}}$ \\
$\mathrm{PL}^{6}$ & $116.8^{\mathrm{d}}$ & $60.60^{\mathrm{bc}}$ & $17.70^{\mathrm{bc}}$ & $11.20^{\mathrm{b}}$ \\
$\mathrm{SO}^{6}$ & $148.2^{\mathrm{bc}}$ & $66.20^{\mathrm{ab}}$ & $18.20^{\mathrm{bc}}$ & $12.60^{\mathrm{ab}}$ \\
$\mathrm{PO}^{6}$ & $186.6^{\mathrm{a}}$ & $78.30^{\mathrm{a}}$ & $24.60^{\mathrm{a}}$ & $14.40^{\mathrm{a}}$ \\
Pooled SE & 7.12 & 2.47 & 0.90 & 0.36 \\
$P$ value & 0.00 & 0.001 & 0.001 & 0.01 \\
\hline
\end{tabular}

$410 \quad{ }^{1}$ Values are presented as means of three replications. Means in the same column with different superscripts are significantly different $411 \quad(P<0.05)$.

$412{ }^{2} \mathrm{ACC}$, Acetyl-coa carboxylase.

$413{ }^{3}$ LPL, Lipoprotein lipase.

$414 \quad{ }^{4} \mathrm{CPT}$ I, Carnitine palmitoyltransferase I.

$415{ }^{5} \mathrm{CPT}$ II, Carnitine palmitoyltransferase II.

$416 \quad{ }^{6}$ FO, Fish oil; PF, PF, Poultry fat; PL, Pork lard; SO, Soybean oil; PO, Palm oil. 